recent reponts. ${ }^{2}$ It is recommended that potentially lethal infection with Str. pneumoniae or $H$. influenzae be seriously considered in any asplenic patient with pyrexia which is not readily explained and, if leucocytosis is found, that treatment with ampicillin be commenced immediately after obtaining blood for culture. Asplenic patients presenting with meningitis or Waterhouse Friderichsen syndrome should be treated with a regimen including an antibiotic effective against both Str. pneumoniae and $H$. influenzae-for example, intravenous ampicillin-until the causal organism has been clearly identified.-I am, etc.,

L. E. RAMSAY Searle Research Fellow,
Scientific Affairs Division
G. D. Searle and Co. Ltd High Wycombe G. D. Searle and Co. Ltd. Bucks

1 Whitaker, A. N., Medical Fournal of Australia, 1969, 1, 1213 .

Ramsay, L. E., and Bouskill, K. C.. Fournal of Annals of Internal Medicine, 1972, 77, 143.

4 Smith, H., Medical Annual, 1973, 91, 278. Horan, M., and Colebatch, J. H., Archives of
Disease in Childhood, 1062, 37, 398 .

Ravry, M., et al., Annals of Internal Medicine, 1972, 77, 11 .

\section{Treatment of Genital Herpes}

SIR,-Your leading article (1 Jume, p. 461) describes the local treatment of genital herpes by incorporating a light-sensitive compound into the virus and then irradiating the infected cells. It also underlines the difficulties of evaluating the results of any form of treatment, especially as one of the most impontant parameters is the subjective index of relief of pain and tenderness in the herpetic lesions. It might have pointed out more emphatically the need to restrict evaluation to the results obtained in cases of primary herpes simplex virus (H.S.V.) infection, as recurrent attacks are usually mild and short-lived.

In genital herpes local applications may be impracticable; the urethra is not uncommonly involved in men and a severe necrotizing œrvicitis is present in at least one-thind of women with primary vulval herpes. Furthermore, in a smaller percentage of partients there are severe comstitutional symptoms, presumably arising from viraemia. A systemic remedy should therefore be our therapeutic goal. Both idoxuridine and cytarabine cause marrow suppression when given systemically and their use would be justified only for life-threatening H.S.V. encephalitis. For the past four years we have used co-trimoxazole in severe cases of primary genital herpes with such good results that we are undertaking a double-blind trial to provide a firm evaluation of this simple, safe, and inexpensive form of treatment. -We are, etc.,

S. M. LAIRD

R. B. ROY

Special Clinic,

Soyal Victoria Hospital,

Bournemouth

Beta-blockade in the Presence of Renal Disease and Hypertension

SIR,-We were most interested in the results of investigations by Drs. F. D. Thompson and A. M. Joekes (8 June, p. 555). They support the widely held impression that beta-blockers do not adversely affect renal function in most hypertensive patients. The results do not, however, provide evidence to refute our suggestion that beta-blockers may cause deterioration in renal function in some patients with chronic renal failure (27 April, p. 193). It is significant that three oonsecutive patients in whom there was an association between detenioration in renal function and the introduction of betablockers were admitted to a specialist renal unit in the space of six months. Having excluded other likely causes of deterioration in renal function we could only conclude that beta-blockade might be responsible. Recen evidence ${ }^{l}$ that the incidence of atherosclerotic heart disease in patients with renal failure is high supports our view that there may be some patients with chronic renal failure who are particularly susceptible to the negative inotropic and chronotropic effects of betablockade on the heart.

We await with interest the full results of the work of Drs. Thompson and Joekes and in particular a detailed analysis of the effects of beta-blockade on renal function in those patients whose creatinine clearance is less than $30 \mathrm{ml} / \mathrm{min}$.-We are, etc.,

DAVID J. WARREN C. P. SwaINSON NOEL WRIGHT

Medical Renal Unit,

Department of Medicine, Royal Infirmary, Edinburgh Lindner, A., et al., New England fournal of
Medicine, 1974, 290, 697.

\section{Puerperal Rubella Vaccination and} Anti-D Immunoglobulin

SIR,-We were interested to read the letter from Mr. B. Alderman and Mr. D. W Charters (29 June, p. 724).

It has been the practice in Bradford to perform rubella haemaglutination inhibition (H.I.) tests routinely in pregnancy at the first antenatal attendance and to offer rubell immunization with Almevax vaccine in the puerperium to women with titres of $1 / 16$ or less. Some of these patients to whom rubella immunization was offered had been given anti-D immunoglobulin, and in view of sug gestions that this might prevent a successful vaccination we have followed up as many patients as possible to see if they had serological rerponse to the rubella vaccine. The number of results so far available is very small. Of four women whose antenatal H.I. titres were less than $1 / 8$ the postvaccination titres were $1 / 128$ in two cases, $1 / 64$ in one, and 1/32 in one. In three of the four cases two additional H.I. tests were done after delivery, before rubella immunization was performed-namely, before and after the administration of anti-D immunoglobulin; all these titres also were less than $1 / 8$. The postvaccination specimens were collected 51-60 days after immunization. Seven women whose prevaccination H.I. titres were $1 / 8$ or $1 / 16$ and who also received anti-D immunoglobulin showed less response and had postvaccination titres which were only 2- or 4-fold higher or remained unchanged.

Though we do not have enough data to permit firm conclusions, it does seem that at least those patients who have no detectable rubella antibodies are likely to develop a satisfactory serological response following rubella vaccination in spite of the prior administration of anti-D immunoglobulin. An extended investigation to confirm our preliminary findings would be desirable, and we should be interested to know the experience of other workers in this field.

We wish to thank the consultant obstetricians in Bradford for their co-operation in this investigation and Dr. R. J. Rand and Dr. Brij B. Khurana for their assistance.

-We are, etc.,

W. M. EDGAR

Bradford Royal Infirmary, Bradford

Virology Department,

Public Health Laboratory,

M. H. HAMBLING

Peeds

\section{Healing of Leg Ulcers}

SIR,-My attention has been drawn to an erroneous reference in my paper "Vertical Leg Drainage of Oedema in Treatment of Leg Ulcers" (15 June, p. 581). The correct reference is Myers, H. B., and Cherry, G. (1971), American Surgeon, 37, 167.

It is possible that my paper conveyed the impression that I considered my healing rates equalled those quoted by Myers and Cherry. This was not my intention; their healing rates were much faster, but their ulcers were much bigger than most of mine, and in the similarly large ulcers in my series the rate was much above my average.

It is worth emphasizing that my method is cheaper, especially in the absence of loss of work time for the patient.-I am, etc.,

Hornchurch, Essex

I. H. J. BOURNE

HI Antibodies to Influenza A/Finland/1/74

SIR,-D During the epidemic season of 1973-4 influenza outbreaks in Finland were caused mainly by B "intermediate" strains, but small outbreaks and scattered cases due to influenza A also occurred throughout the country. From a follow-up study the rate of influenza A infections among adults was clearly below $10 \%$. The 28 influenza A isolates from 21 patients were found to be antigenically closer to A/Port Chalmers/ 1/73 than to the previous variants of Hong Kang virus. The strains studied in the World Influenza Centre differed even from the Port Chalmers strain by showing very low, if any, HI titres with anti-A/Hong Kong/1/68 serum. Similar strains were isolated in the Democratic Republic of Germany, Federal Republic of Germany, ${ }^{1}$ and Norway. ${ }^{2}$

During the recent influenza epidemics an HI titre of $\geqslant 40$ has appeared to confer protection against infection. ${ }^{3}$ In pre-epidemic rera collected in Finland in autumn 1973 from 40 conscripts and from 65 pregnant women the percentages of cases with an HI titre of $\geqslant 48$ to A/Finland/1/74 were 30 and 27. The corresponding percentages of cases with $\mathrm{HI}$ antibodies to A/Hong Kong/ $8 / 68$ were 65 and 75 . In a series of 43 acute phase sera from $A / F i n l a n d / 74$ patients the highest titre of the homologous antibodies was 24.

We have analysed the HI antibody responses of influenza $\mathrm{A}$ patients during the five $\mathrm{H} 3 \mathrm{~N} 2$ epidemics occurring in Finland. All patients were conscripts of 18-21 years. The acute sera had been taken not later than in the fourth day from the onset of illness, 


\begin{tabular}{|c|c|c|c|c|c|}
\hline \multirow{2}{*}{ Epidemic } & \multirow{2}{*}{ Antigen } & \multicolumn{2}{|c|}{$\begin{array}{l}\text { Geometric Mean of Antibody } \\
\text { Titres }\end{array}$} & \multirow{2}{*}{$\begin{array}{c}\text { X-fold } \\
\text { Rise in } \\
\text { Mean Titre }\end{array}$} & \multirow{2}{*}{$\begin{array}{l}\text { Proportion of } \\
\text { Cases with } \\
\geqslant 4 \text {-fold } \\
\text { Rise in } \\
\text { Titres }\end{array}$} \\
\hline & & $\begin{array}{l}\text { Acute Phase } \\
\text { Sera }\end{array}$ & $\begin{array}{l}\text { Convalescent } \\
\text { Phase Sera }\end{array}$ & & \\
\hline $1968-9$ & $\begin{array}{l}\text { Hong Kong/8/68 } \\
\text { MRC-2 } \\
\text { MRC-10 } \\
\text { Finland/1/74 }\end{array}$ & $\begin{array}{l}6 \\
6 \\
6 \\
6\end{array}$ & $\begin{array}{r}213 \\
30 \\
19 \\
15\end{array}$ & $\begin{array}{c}36 \\
5 \\
3 \\
2 \cdot 5\end{array}$ & $\begin{array}{l}20 / 20 \\
14 / 20 \\
10 / 20 \\
10 / 20\end{array}$ \\
\hline $1969-70$ & $\begin{array}{l}\text { Hong Kong/8/68 } \\
\text { MRC-2 } \\
\text { MRC-10 } \\
\text { Finland/1/74 }\end{array}$ & $\begin{array}{l}7 \\
7 \\
6 \\
6\end{array}$ & $\begin{array}{r}411 \\
59 \\
26 \\
19\end{array}$ & $\begin{array}{r}59 \\
8 \\
4 \\
3\end{array}$ & $\begin{array}{r}10 / 10 \\
8 / 10 \\
7 / 10 \\
5 / 10\end{array}$ \\
\hline $1971-2$ & $\begin{array}{l}\text { Hong Kong/8/68 } \\
\text { MRC-2 } \\
\text { MRC-10 } \\
\text { Finland/1/74 }\end{array}$ & $\begin{array}{l}6 \\
6 \\
6 \\
6\end{array}$ & $\begin{array}{r}245 \\
46 \\
24 \\
19\end{array}$ & $\begin{array}{r}41 \\
8 \\
4 \\
3\end{array}$ & $\begin{array}{l}20 / 20 \\
17 / 20 \\
15 / 20 \\
13 / 20\end{array}$ \\
\hline $1972-3$ & $\begin{array}{l}\text { Hong Kong/8/68 } \\
\text { MRC-2 } \\
\text { MRC-10 } \\
\text { Finland/1/74 }\end{array}$ & $\begin{array}{r}17 \\
9 \\
6 \\
6\end{array}$ & $\begin{array}{l}220 \\
227 \\
138 \\
162\end{array}$ & $\begin{array}{l}13 \\
25 \\
23 \\
27\end{array}$ & $\begin{array}{l}24 / 25 \\
25 / 25 \\
25 / 25 \\
25 / 25\end{array}$ \\
\hline 1974 & $\begin{array}{l}\text { Hong Kong/8/68 } \\
\text { MRC-2 } \\
\text { MRC-10 } \\
\text { Finland/1/74 }\end{array}$ & $\begin{array}{r}26 \\
18 \\
7 \\
7\end{array}$ & $\begin{array}{l}244 \\
214 \\
143 \\
229\end{array}$ & $\begin{array}{r}9 \\
12 \\
20 \\
33\end{array}$ & $\begin{array}{l}40 / 43 \\
38 / 43 \\
42 / 43 \\
43 / 43\end{array}$ \\
\hline
\end{tabular}

Titres of $<12$ are regarded as 6 .

and the convalescent sera in the 11-26th day. The treatment of sera and the HI tests were done as described previously." With the exception of $\mathrm{A} / \mathrm{Finland} / 1 / 74$ the strains used for preparation of antigens were $a b-$ tained, through the courtesy of Dr. G. C. Sohild, from the World Influenza Centre. The recombinant strain, MRC-2, is antigenically identical with $A /$ England/42/72 and the MRC-10 strain with A/Port Chalmers/1/73. The results from the five epidemics are summarized in the table.

Comparatively high antibody titres to A/Finland/1/74 were evoked by A/England/ $42 / 72$ infections during the 1972-3 epidemic. In contrast, the sera collected during the previous years did not attain the fourfold increase in the geometric mean titre with A/Finland/1/74, though about half of the cases showed a significant increase of $A / F$ inland/1/74 antibodies (usually from $<12$ to 24). The highest increase was from

$<12$ to 96 in two cases out of 50 Hong Kong patients. In the earlier convalescent sera a titre of $\geqslant 48$ was present in only nine cases. taining the original Hong Kong virus are unlikely to raise $\mathrm{HI}$ antibodies against strains like $\mathrm{A} / \mathrm{Finland} / 1 / 74$ to a level consistent with immunity.

A preliminary survey of $\mathrm{HI}$ antibodies to A/Finland/1/74 in June 1974 suggests that in spite of the recent epidemic the immune status in the beginning of the next epidemic season in Finland will be even poorer than in autumn 1973.-We are, etc.,

\section{R. PYHÄL}

Central Public Health Laboratory, K. Cantel

\section{Weekly Epidemiological Record, 1974, 49, 107. \\ 2 Weekly Epidemiological Record, 1974, 49, 176.} 3 Pereira, M. A., et al., British Medical fournal, $1972,4,701$.
4yhälä, R., and Kleemola, M., Scandinavia
fournal of Infectious Diseases, 1973, 5, 273. These findings suggest that vaccines con-

\section{Serum Calcitonin and Thyroid Carcinoma}

SIR,-The suggestion in your leading article (1 June, p. 461) that the finding of a raised serum calcitonin level in a member of a family with a high incidence of medullary carcinoma is an indication for total thyroidectomy is based on several assumptions.

Firstly, it assumes that hypercalcitoninaemia in these families is always due to excessive production of calcitonin by thyroid C cells. Hypercalcitoninaemia has been reported in a number of conditions other than medullary carcinoma ${ }^{1-3}$ and we have found that it occurs frequently in patients with non-thyroid tumours." The recent account of production by oat cell carcinomas of the lung $^{5}$ draws attention to extra-thyroidal sources of calcitonin.

The second assumption is that hypercalcitoninaemia identifies a malignant or premalignant state of the thyroid $C$ cells. Individual members of these families who have had a thyroidectomy on the basis of hypercalcitoninaemia have shown histological changes which are consistent with increased numbers and activity of thyroid $C$ cells. ${ }^{6-8}$ Though it appears that the level of calcitonin progressively increases in members who have only hyperplastic changes it remains to be seen if this condition inevitably progresses to a malignant one.

The third and most important assumption
The measurement of serum calcitonin there is a relatively greater risk of developing symptoms due to medullary carcinoma or phaeochromocytoma. In addition, it is useful helps to define those members in whom in following the extent and activity of the C-cell system. Other clinical and laboratory ${ }^{13}$ findings may prove of value in further selection of individuals at risk. Decisions regarding the type of treatment, especially of asymptomatic members, by procedures having finite risks should be made only after careful consideration of the likely natural his:ory of the "disease" and the "illness" in the individual concerned.-We are, etc.,

\section{Peter Greenberg} IAIN MACINTYRE

Royal Postgraduate Medical School,

Hammersmith Hospital,

Sizemore, G. W., et al., New England fournal of Medicine, 1973, 288, 641.

Deftos. L. J., et al., fournal of Clinical Investigation, 1973, 52, 3109.

3 Milhaud, G., et al., Lancet, 1974, 1, 462.

Coombes, R. C., et al., Lancet, 1974, 1, 1080.

Silva, O. L., et al., New England fournal of Medicine, 1974, 290, 1122.

Melvin, K. E. W., Tashjian, A. H., and Miller, 1972, 28, 399 .

Wolfe, H. J., et al., New England fournal of Medicine, 1973, 289, 437.

Jackson, C. E., Tashjian. A. H., and Block, 845 .

9 Ljungberg. O., Acta Pathologica et Microbiologica Scandinavica, 1972, Suppl. no. 231 . p. 10.

11 Galante, L., et al., Lancet, 1968, 2, 537. G. E., in Carvalheira, A. F., and Pearse, A. G. E., in
Calcitonin, ed. S. Taylor, p. 122. London, Heinemann, 1968.

12 Ljungberg, O.,, Cederquist, E., and Studnitz, W. 3 von, British Medical fournal, 1967, 1, 279 . Institute, 1974, 52, 285.

\section{Toxic Reaction to Phenytoin}

SIR,-In the light of the paper by Drs. D. L. McLellan and M. Swash (27 April, p. 204) we should like to report the following case recently under our care.

The patient originally presented at the age of 11 months with febrile convulsions. Her birth was normal and there was no family history of epilepsy. She was started on phenobarbitone but two months later had a second series of convulsions two months later had a second series of convulsions and phenytoin was added. Over the next three
years she was admitted to hospital on six occasions years she was admitted to hospital on six occasions for further convulsions and was treated with various combinations of phenytoin, ethoxusimide, chlorpromazine, and beclamide with little success. Her E.E.G. showed some abnormal spike activity and her I.Q. progressively fell from 75 on the Wechsler scale in 1967 to 51 in 1971. Extensive investigation revealed no definite aetiology and she was thought to be suffering from some degenerative condition of the brain. In February 1974, aged 11 years, she was moderately controlled on phenytoin $400 \mathrm{mg}$ and primidone $500 \mathrm{mg}$ daily when she suddenly developed choreoathetoid movements of all her limbs and jerking movements of her tongue and facia! muscles. She rapidly of her tongue and facia! muscles. She rapidly
became uncontrollable and was sedated with became uncontrollable and was sedated with intravenous diazepam. The serum phenytoin level was $42 \mu \mathrm{g} / \mathrm{ml}$. The drug was reduced to $240 \mathrm{mg}$ daily and the dyskinetic movements disappeared. However, her convulsions became worse and after discharge from hospital the phenytoin was increased
again to $400 \mathrm{mg}$ daily. She was readmitted two weeks later with a recurrence of the choreoathetosis. It was concluded that this was a toxic reaction to phenytoin. She was taken off this and started on carbamazepine. The dyskinetic movements rapidly ceased and the patient became generally easier to control and more orientated. Her convulsions remain in satisfactory control.

Initially we were cautious about calling this phenytoin toxicity in view of the lack of such descriptions in the literature. However, the diagnosis later became obvious when the symptoms were abolished by reducing the dose of phenytoin and then returned on increasing it. As in the cases described by Drs. McLellan and Swash our patient was on a combination of phenytoin and primidone. When high doses are required it is often a question of which is less 